\title{
Antiinflammatory and antinociceptive activities of Zingiber officinale Roscoe essential oil in experimental animal models
}

Ginger, Zingiber officinale Roscoe (Zingiberaceae), in folk medicine has been used against pain, inflammation, arthritis, urinary infections, and gastrointestinal disorders. ${ }^{[1]}$ The oil of ginger is a mixture of constituents, consisting of monoterpenes (phellandrene, camphene, cineole, citral, and borneol) and sesquiterpenes (zingiberene, zingiberol, zingiberenol, B-bisabolene, sesquiphellandrene, and others). Aldehydes and alcohols are also present. ${ }^{11,2]}$

Gingerol and its analogs found in rhizome extracts are responsible for many pharmacological activities. ${ }^{[1]}$ Few works have reported the properties of ginger essential oil (GEO). However, several types of terpene compounds are known to present antiinflammatory and antinoceptive activities. ${ }^{11,2]}$

The aim of the present study was to evaluate the antiinflammatory and analgesic effects of GEO administered orally in rodents. Groups of 10 male Swiss mice (25-30 g) and male Wistar rats (190-230 g) were used for evaluation of the antinoceptive and antiinflammatory effects, respectively. All animals were housed in groups of five and maintained in standardized conditions $\left(12 / 12 \mathrm{~h}\right.$ light/dark cycle, $\left.25^{\circ} \mathrm{C}\right)$ with free access to water and food. The protocol for these experiments was approved and was in accordance with the guidelines of the Brazilian Committee of Animal Experimentation.

Fresh rhizomes of $Z$. officinale were collected from the herbarium of the State University of Maringá, identified, and authenticated. GEO was obtained from $250 \mathrm{~g}$ of rhizomes by conventional steam distillation using Clevenger apparatus during $3 \mathrm{~h}$. The oil obtained was kept refrigerated and protected form direct light.

Pleurisy was induced in anesthetized mice by intraperitoneal (i.p.) injection of carrageenan (200 $\mu \mathrm{g} /$ cavity). Four hours later, the rats were sacrificed and the exudate was collected to determine the total volume and leukocyte number. Exudates smears were prepared, air-dried, and fixed with Rosenfeld stain for leukocyte differential count. The parameters studied were leukocyte migration and fluid leakage. GEO $(100,200$, and $500 \mathrm{mg} / \mathrm{kg}$, p.o.) and indomethacin $(5 \mathrm{mg} / \mathrm{kg}$, p.o.) were administered $30 \mathrm{~min}$ before the test.

The antinociceptive activity of the GEO was assessed using the writhing test. Acetic acid solution $(10 \mathrm{ml} / \mathrm{kg}, 0.6 \%)$ was i.p. injected and abdominal muscles constriction together with stretching of the hind limbs was counted over a period of 20 min, starting immediately after acetic acid injection. GEO (50, 100 , and $200 \mathrm{mg} / \mathrm{kg}$, p.o.) and indomethacin $(5 \mathrm{mg} / \mathrm{kg}$, p.o.) were administered 30 min before the acid injection. Antinociceptive activity was expressed as the percentage of inhibition of writhings compared with control animals.

The hot-plate test was performed to measure response latencies. The hot plate was maintained at $55.0 \pm 1^{\circ} \mathrm{C}$. The time taken (s) to cause a discomfort reaction (licking paws or jumping) was recorded as the response latency $0,15,30,60$, and $90 \mathrm{~min}$ after administration of GEO (100 and $200 \mathrm{mg} / \mathrm{kg}$, p.o.), meperidine (50 mg/kg, i.p.) or saline solution $0.9 \%$ (control group). A latency period of $25 \mathrm{~s}$ was defined as complete analgesia and the experiment was stopped if it exceeded the latency period in order to avoid injury.

Data are reported as mean \pm SEM. Statistical differences in all groups were determined using one-way ANOVA. $P$ values $<0.05$ were considered significant.

In the pleurisy test, indomethacin and GEO 200 and 500 $\mathrm{mg} / \mathrm{kg}$ reduced significantly the exudate volume $(\mathrm{P}<0.05$ and $\mathrm{P}<0.001$ ) without promoting alteration of total leukocyte migration. [Table 1] Data suggest that GEO does not have

\section{Table 1}

Exudate volume and leukocyte number count $4 \mathrm{~h}$ after carrageenan injection (200 $\mathrm{mg}$ into the pleural cavity) in treated (GEO or indomethacin) and nontreated rats

\begin{tabular}{|c|c|c|c|c|}
\hline Groups & $\begin{array}{c}\text { Exudate } \\
\text { volume }(\mathrm{ml})\end{array}$ & $\begin{array}{l}\text { Leukocyte count } \\
\left(\text { cells } / \mathrm{mm}^{3}\right) \times 10^{3}\end{array}$ & $\begin{array}{l}\text { Cells } \\
\text { MN }\end{array}$ & $\begin{array}{l}x 10^{6} \\
P M N\end{array}$ \\
\hline Control & $1.05 \pm 0.07$ & $68250 \pm 3056$ & $15 \pm 2$ & $49 \pm 5$ \\
\hline $\begin{array}{l}\text { Indomethacin } \\
(5 \mathrm{mg} / \mathrm{kg})\end{array}$ & $0.52 \pm 0.02^{*}$ & $63180 \pm 4207$ & $14 \pm 1$ & $49 \pm 4$ \\
\hline $\begin{array}{l}\text { GEO } \\
(100 \mathrm{mg} / \mathrm{kg})\end{array}$ & $0.88 \pm 0.05$ & $56100 \pm 2905$ & $15 \pm 1$ & $41 \pm 2$ \\
\hline $\begin{array}{l}\text { GEO } \\
(200 \mathrm{mg} / \mathrm{kg})\end{array}$ & $0.80 \pm 0.06^{* *}$ & $60380 \pm 3884$ & $15 \pm 2$ & $45 \pm 4$ \\
\hline $\begin{array}{l}\text { GEO } \\
(500 \mathrm{mg} / \mathrm{kg})\end{array}$ & $0.69 \pm 0.06^{*}$ & $62080 \pm 3469$ & $13 \pm 2$ & $49 \pm 4$ \\
\hline
\end{tabular}

Values are mean \pm SEM. $n=$ number of animals in each group (10). MN, mononuclear leukocytes; PMN, polymorphonuclear leukocyte. * $P<0.001$ compared with control values. ${ }^{* \star} P<0.05$ compared with control values.

influence on cells' recruitment, different to that observed for others essential oils ${ }^{[3]}$ The antiinflammatory activities of compounds obtained from GEO have been reported by other investigations using ginger extract. ${ }^{[1]}$ These antiinflammatory actions could be owing to the inhibition of prostaglandin release, and hence ginger may act in a way similar to other nonsteroidal antiinflammatory drugs which interfere with prostaglandin biosynthesis. Gingerol has been reported to have antiinflammatory actions, which include suppression 


\section{Table 2}

Effects of GEO (Z. officinale) on acetic acid-induced writhing

\begin{tabular}{lcc}
\hline Group & No. of writhings & $\begin{array}{c}\text { Percentage inhibition } \\
\text { (\%) }\end{array}$ \\
\hline Control & $70.4 \pm 3.2$ & - \\
Indomethacin $(5 \mathrm{mg} / \mathrm{kg})$ & $44.4 \pm 1.2^{* *}$ & 36.9 \\
GEO $(50 \mathrm{mg} / \mathrm{kg})$ & $54.1 \pm 2.9^{*}$ & 23.2 \\
GEO $(100 \mathrm{mg} / \mathrm{kg})$ & $54.9 \pm 3.6^{*}$ & 22.0 \\
GEO $(200 \mathrm{mg} / \mathrm{kg})$ & $35.5 \pm 5.4^{* *}$ & 49.6 \\
\hline
\end{tabular}

Values are mean \pm SEM. $n=$ number of animals in each group (10). ${ }^{*} P$ $<0.05$ compared with control values. ${ }^{\star \star} P<0.001$ compared with control values.

of both cyclooxygenase and lipooxygenase metabolites of arachidonic acid. ${ }^{[4]}$ Furthermore, constituents of essential oils obtained from many other plants have been proposed to have antiinflammatory activity. ${ }^{[1]}$

Essential oils' constituents such as (-)-linalool antagonize different pain responses elicited by exposure to a chemical stimulus such as acetic-induced, by a thermal stimulus or by a tissue injury produced by formalin injection. ${ }^{[5]}$ Suekawa $e t$ al. ${ }^{[2]}$ showed analgesic and antipyretic properties from ginger extracts in a range of laboratory animals. In the present experiments, GEO (50, 100, and $200 \mathrm{mg} / \mathrm{kg}$, p.o.) and indomethacin significantly suppressed the acetic acid-induced writhing response in a dose-dependent manner (Table 2). Maximum inhibition of GEO was observed at the dose of 200 $\mathrm{mg} / \mathrm{kg}$.

In the hot-plate test, the time course of the antinociceptive reaction produced by saline or GEO (100 and $200 \mathrm{mg} / \mathrm{kg}$ ) administration did not result in significant prolongation of the response latency as observed for meperidine group animals (data not shown).

GEO was found to contain monoterpenes and sesquiterpenes as principal compounds, ${ }^{[1,2]}$, suggesting that the antiinflammatory and analgesic effects could be correlated to these essential oil constituents. Further studies are needed to reveal the mechanisms of action for these activities of GEO.

\section{A. Vendruscolo, I. Takaki, L. E. Bersani-Amado, J. A. Dantas, C. A. Bersani-Amado,} R. K. N. Cuman

Department of Pharmacy and Pharmacology, University of Maringá, 87020-900, Maringá, PR, Brazil.

E-mail: rkncuman@uem.br

\section{References}

1. Tang W, Eisenbrand G. Chinese drugs of plant origin. Chemistry, pharmacology and use in traditional and modern medicine. $1^{\text {st }}$ edn. Kaiserslautern. Berlin: Springer-Verlag; 1992.

2. Suekawa M, Ishige A, Yuasa K, Sudo K, Aburada M, Hosoya E. Pharmacological studies on ginger. I. Pharmacological actions of pungent constituents, (6)-gingerol and (6)-shogaol. J Pharmacobiodyn 1984;7:836-48.

3. Abe S, Maruyama N, Hayama K, Inouye S, Oshima H, Yamaguchi H. Supression of neutrophil recruitment in mice by geranium essential oil. Mediat Inflam 2004;13:21-4.

4. Thompson M, Al-Qattan KK, Al-Sawan SM, Alnaqeeb MA, Khan I, Ali M. The use of ginger (Zingiber officinalle Rosc.) as a potential anti-inflammatory and antithrombotic agent. Prostagland Leukotrien Essent Fat Acid 2002;67:475-8.

5. Peana AT, D'Aquila PS, Chesa ML, Moretti MD, Serra G, Pippia P. (-)Linalool produces antinociception in two experimental models of pain. Eur J Pharmacol 2003;460:37-41.

\section{IJP STARTS SHARING REPRINT REVENUE WITH AUTHORS}

Starting 2005, IJP took a policy decision, to reward authors for their contributions which bring in reprint revenue for the journal. Sale of reprints adds to the financial stability of the journal, while propagating knowledge transmitted by its contributors. Sharing of the reprint revenue by the journal is expected to motivate authors for better quality inputs to the IJP. This practice will be more rewarding for the journal as well as the authors

In 2005, IJP sold reprints for more than one lakh rupees. A German company, bought reprint rights of the paper "Ginger as an antiemetic in nausea and vomiting induced by chemotherapy: a randomized, crossover, double blind study " which was contributed by Smita Sontakke, Vijay Thawani and Meena Naik from Government Medical College, Nagpur (IJP, Feb 2003, 35: 32-36). The chief editor gave away $10 \%$ of the reprint revenue to the authors by presenting them with a cheque for Rs 12,000 during the Annual Conference of the IPS at Chennai in December 2005.

The IJP congratulates the first recipients of the "reprint share scheme" and hopes they would utilize this amount for academic pursuit. 